\section{L.F. da Rocha Jr, et al reply}

\section{To the Editor:}

We thank Xie and colleagues for their comments ${ }^{1}$ on our article ${ }^{2}$ and for applying expertise to this question of interleukin 22 (IL-22) as a possible therapeutic target in rheumatoid arthritis (RA) and as a promising candidate biomarker.

Novel cytokines have emerged recently as contributing to the pathogenesis of autoimmune diseases. Knowledge about the role of IL-22 in autoimmune diseases is increasing and may reveal new therapeutic options for modulation of this cytokine. The role of IL-22 has been investigated in other inflammatory autoimmune diseases, such as psoriasis ${ }^{3}$ and psoriatic arthritis $^{4}$, systemic sclerosis ${ }^{5}$, and systemic lupus erythematosus ${ }^{6}$.

In RA, IL-22 is also a promising candidate biomarker as a predictor of disease activity. We demonstrated that higher serum levels of this cytokine are associated with more severe disease ${ }^{2}$. The association of IL-22 with bone erosions supports the idea that this cytokine may play a role in destructive bone disease. IL-22 may also be associated with pannus formation ${ }^{4}$.

Th17 and Th22 subsets are major sources of IL-22. These cell lineages were significantly increased in the peripheral blood of patients with inflammatory arthritis, such as ankylosing spondylitis and $\mathrm{RA}^{7,8}$. Although we did not investigate these cell subsets, we were able to show that IL-22 levels are high in patients with RA, indicating a role of this cytokine within the complex and heterogeneous pathogenesis of RA.

New strategies for RA treatment focusing on IL-22 may reveal alternative therapies for those patients who remain refractory to current therapeutic modalities. Antibodies to this cytokine might become available in the future. The monoclonal antibody fezakinumab, which modulates expression of IL-22, has been studied in a Phase II trial, but the study was discontinued $^{9}$. The role of IL-22 in protection against bacterial infection should be kept in mind $^{10}$. The nuclear receptor peroxisome proliferator-activated receptor- $\gamma$ agonists currently under study may also represent a molecular target in autoimmune diseases such as RA, as they were found to suppress the expression of IL-22 ${ }^{11}$.

The benefit of rituximab, a monoclonal antibody directed to CD20 antigen on B cells, is recognized in the treatment of RA. In a recent study of 12 patients with active RA disease who were resistant to TNF blockade, lower mRNA levels of IL-22 in synovial tissue were described after rituximab treatment ${ }^{12}$. Thus, IL-22 suppression is probably one of the mechanisms involved in rituximab therapy. The Janus kinase inhibitor tofacitinib has been shown to be an inhibitor of IL-22 expression, and may represent a strategy in the treatment of RA ${ }^{13}$.

Finally, genetic studies would be helpful in clarifying the role of IL-22 in RA as a biomarker or as a potential therapeutic target.

LAURINDO FERREIRA da ROCHA Jr, MS Student, Laboratório de Imunomodulação e Novas Abordagens Terapêuticas and Serviço de Reumatologia do Hospital das Clínicas da UFPE; ÂNGELA LUZIA BRANCO PINTO DUARTE, PhD, Serviço de Reumatologia do Hospital das Clínicas da UFPE; ANDRÉA TAVARES DANTAS, PhD Student; HENRIQUE ATAÍDE MARIZ, PhD Student, Laboratório de Imunomodulação e Novas Abordagens Terapêuticas and Serviço de Reumatologia do Hospital das Clínicas da UFPE; IVAN da ROCHA PITTA, PhD; SUELY LINS GALDINO, PhD, Laboratório de Planejamento e Síntese de Fármacos da UFPE; MAIRA GALDINO da ROCHA PITTA, PhD, Laboratório de Imunomodulação e Novas Abordagens Terapêuticas da UFPE, Universidade Federal de Pernambuco (UFPE), Brazil. Address correspondence to Dr. M.G.R. Pitta, UFPE, Centro de Ciências Biológicas, Departamento de Bioquímica, Av. Prof. Moraes Rego, 1235, Cidade Universitária, Recife PE, 50670-901, Brazil.

E-mail: mgrpitta@gmail.com

\section{REFERENCES}

1. Xie Q, Wang S-C, Li J. Interleukin 22, a potential therapeutic target for rheumatoid arthritis [letter]. J Rheumatol 2012;39:xxxxx.

2. Da Rocha LF Jr, Duarte AL, Dantas AT, Mariz HA, Pitta ID, Galdino SL, et al. Increased serum interleukin 22 in patients with rheumatoid arthritis and correlation with disease activity. J Rheumatol 2012;39:1320-5.

3. Kagami S, Rizzo HL, Lee JJ, Koguchi Y, Blauvelt A. Circulating Th17, Th22, and Th1 cells are increased in psoriasis. J Invest Dermatol 2010;130:1373-83.

4. Mitra A, Raychaudhuri SK, Raychaudhuri SP. Functional role of IL-22 in psoriatic arthritis. Arthritis Res Ther 2012;14:R65.

5. Mathian A, Parizot C, Dorgham K, Trad S, Arnaud L, Larsen M, et al. Activated and resting regulatory $\mathrm{T}$ cell exhaustion concurs with high levels of interleukin-22 expression in systemic sclerosis lesions. Ann Rheum Dis 2012;71:1227-34.

6. Qin WZ, Chen LL, Pan HF, Leng RX, Zhai ZM, Wang C, et al. Expressions of IL-22 in circulating CD4+/CD8+ T cells and their correlation with disease activity in SLE patients. Clin Exp Med 2011;11:245-50.

7. Zhang L, Li JM, Liu XG, Ma DX, Hu NW, Li YG, et al. Elevated Th22 cells correlated with Th17 cells in patients with rheumatoid arthritis. J Clin Immunol 2011;31:606-14.

8. Zhang L, Li YG, Li YH, Qi L, Liu XG, Yuan CZ, et al. Increased frequencies of Th22 cells as well as Th17 cells in the peripheral blood of patients with ankylosing spondylitis and rheumatoid arthritis. PLoS One 2012;7:e31000.

9. Pfizer Pipeline - Our medicines in development. Pfizer Inc.; May 10, 2012. [Internet. Accessed July 27, 2012.] Available from: http://www.pfizer.com/pipeline

10. Zheng Y, Valdez PA, Danilenko DM, Hu Y, Sa SM, Gong Q, et al. Interleukin-22 mediates early host defense against attaching and effacing bacterial pathogens. Nat Med 2008;14:282-9.

11. Klotz L, Burgdorf S, Dani I, Saijo K, Flossdorf J, Hucke S, et al. The nuclear receptor PPAR gamma selectively inhibits Th17 differentiation in a T cell-intrinsic fashion and suppresses CNS autoimmunity. J Exp Med 2009;206:2079-89.

12. van de Veerdonk FL, Lauwerys B, Marijnissen RJ, Timmermans K, Di Padova F, Koenders MI, et al. The anti-CD20 antibody rituximab reduces the Th17 cell response. Arthritis Rheum 2011;63:1507-16.

13. Migita K, Miyashita T, Izumi Y, Koga T, Komori A, Maeda Y, et al. Inhibitory effects of the JAK inhibitor CP690,550 on human CD4(+) T lymphocyte cytokine production. BMC Immunol 2011;12:51.

J Rheumatol 2012;39:11; doi:10.3899/jrheum.120876 